\title{
THE EFFECTIVENESS TEST OF ORGANIC ACIDS AS A PRESERVATIVE OF ANIMAL FEED INGREDIENTS
}

\section{UJI EFEKTIVITAS ASAM ORGANIK SEBAGAI PENGAWET BAHAN PAKAN HEWAN}

\author{
ADISTI RIZQA ${ }^{1 *}$, WIJAYANTI INDAH ${ }^{2}$, and RETNANI YULI ${ }^{2}$ \\ ${ }^{1}$ Mahasiswa Pascasarjana Fakultas Peternakan Institut Pertanian Bogor \\ ${ }^{2}$ Dosen Fakultas Peternakan Institute Pertanian Bogor \\ Jalan Agatis, Kampus IPB Dramaga Bogor 16680, Indonesia \\ e-mail : rizqaptk233@gmail.com
}

\begin{abstract}
ABSTRAK
Penelitian ini dilaksanakan di Laboratorium Teknologi Industri Pakan Fakultas Peternakan Institut Pertanian Bogor Bogor. Tujuan dari penelitian ini adalah untuk mengetahui efektivitas penggunaan asam organik sebagai pengawet pada bahan pakan berupa pollard dan dedak gandum berdasarkan parameter fisik. Penelitian ini menggunakan Rancangan Acak Lengkap dengan 2 faktorial berupa jenis pakan dan jenis asam organik dengan 5 ulangan, sampel disimpan selama 6 minggu kemudian dilakukan pengambilan data berupa kadar air, sudut tumpukan, kerapatan tumpukan dan berat jenis. Hasil penelitian menunjukkan bahwa asam organik mempengaruhi kadar air tetapi tidak berpengaruh terhadap kerapatan tiang, sudut tiang dan berat jenis. Jenis pakan mempengaruhi nilai kadar air, sudut tumpukan, kerapatan tiang dan berat jenis. Berdasarkan hasil uji indeks efektivitas, diketahui bahwa nilai rendemen total pada pollard dengan asam laurat 1\% adalah 0,64, asam sorbat 0,35 dan asam propionat adalah 0,77, sedangkan dedak gandum dengan asam laurat adalah 1,07 pada -1 sorbat. AC id. 0,39 dan dalam asam propionat 2,64. Kesimpulan dari penelitian ini adalah asam propionat dapat digunakan sebagai pengawet pollard dan dedak gandum.
\end{abstract}

Kata kunci : Asam propionat, asam lauric, asam sorbat, pollard, dedak gandum

\begin{abstract}
This research was conducted in the Laboratory of Feed Industry Technology, Faculty of Animal Husbandry, Bogor Agricultural University, Bogor. The purpose of this study was to determine the effectiveness of using organic acids as preservatives in feed ingredients in the form of pollard and wheat bran based on physical parameters. This study used a completely randomized design with 2 factorials in the form of feed type and organic acid type with 5 replications, samples were stored for 6 weeks, and then data were collected in the form of moisture content, pile angle, pile density, and specific gravity. The results showed that organic acids affected the moisture content but had no effect on pile density, pile angle, and specific gravity. The type of feed affects the value of moisture content, pile angle, pile density, and specific gravity. Based on the results of the effectiveness index test, it is known that the total yield value on pollard with $1 \%$ lauric acid is 0.64 , sorbic acid is 0.35 and propionic acid is 0.77 , while wheat bran with lauric acid is 1.07 at -1 sorbic acid. .39 and in propionic acid 2.64. This research concludes that propionic acid can be used as a preservative for pollard and wheat bran.
\end{abstract}

Keywords: Propionic acid, lauric acid, sorbic acid, pollard, wheat bran

\section{INTRODUCTION}

The addition of preservatives in food has been commonly done but for feed ingredients not much has been done this is due to the opinion that feed ingredients will be directly processed into feed. Whereas feed ingredients undergo a process of harvesting and storage before being transported, all of which require time, while at that time the quality and quality of feed ingredients continues to decline. The decline in the quality of feed ingredients will certainly cause the feed produced to have poor quality.

Damage to feed ingredients in the form of pollard and wheat bran during the harvesting and storage process can be caused by the growth of microorganisms and chemical processes in the feed ingredients themselves. Several methods of preservation that have been commonly used in food are by providing chemical preservatives 
such as benzoic acid and its salt, but their safety continues to be questioned. This, of course, raises a worry, on the one hand, there is a demand for preservation while on the other hand, the health of livestock will be at stake. Therefore, it is necessary to look for safe preservatives so that the health of livestock is maintained and the quality of feed ingredients is guaranteed during storage. Natural preservatives such as organic acids and their esters are promising.

Organic acids are commonly found in the plant, animal, and microorganism cells. Several types of organic acids have antimicrobial activity so that they can be used as preservatives. Types of organic acids that can be used include sorbic acid, lauric acid, and propionic acid. Sorbic acid is more effective at high acidity than benzoic acid. Potassium sorbate is used in the manufacture of cakes, cheese, and cheese products, and in some semi-wet foods, it acts as an antimycotic or anti-fungal agent (Sukasih, 2016).

According to Patty (2015), Lauric acid only requires a concentration of 0.062 $\mathrm{micromol} / \mathrm{ml}$ and can inhibit Pneumococcus. The capric acid and myristic acid, respectively, need $1.45 \mathrm{micromol} / \mathrm{ml}$ and $0.218 \mathrm{micromol} / \mathrm{ml}$ to inhibit the same microbes. Propionic acid is generally used as an anti-mold (anti-fungal) raw material in animal feed. As much as $50 \%$ of propionic acid is used in anti-mold, this shows that propionic acid can be used as a preservative in pollard and wheat bran (Nosal, 2019). According to Nosal (2019), calcium propionate can be added to all types of feed with an additional amount of less than $0.3 \%$ which can inhibit the growth of aspergillus in the 2 nd week of silage.

Pollard itself is the outermost part of the wheat husk in the form of coarse flakes and is widely used as feed for cattle and sheep. While wheat bran is a by-product of wheat that comes from the inside of the wheat husk in the form of fine flakes that are smaller than pollard and are usually used in small animal feed such as poultry. The purpose of this study was to determine the effect of organic acid on the physical parameters of pollard and wheat bran.

\section{MATERIALS and METHODS}

This research was conducted in the feed industry technology laboratory. The tools and materials used in this study were pollards, wheat bran, sorbic acid, propionic acid, lauric acid, plastic trays, analytical scales, digital thermometer, oven $105^{\circ} \mathrm{C}$, funnel, ruler, $250 \mathrm{ml}$ measuring cup.

The procedure in this study used a completely randomized design (CRD) with 2 factors with the first factor being feed ingredients (pollard and wheat bran) and the second factor being organic acids (sorbic acid, propionic acid, lauric acid) with 5 replications each. Pollard and wheat bran to be observed were divided into 4 treatments by adding organic acid as much as $1 \%$ of the sample. then stored for 6 weeks. Pollard as much as $40 \mathrm{~kg}$ is divided into 4 parts where each part becomes $10 \mathrm{~kg}$. Each part was added with organic acid according to the treatment layout and then stored in a plastic container. This method is also carried out on wheat bran. Samples were stored in a room that was not exposed to direct sunlight for 6 weeks.

\section{Parameters}

The research parameters in this study were based on physical tests of feed ingredients in the form of measurements of specific gravity, pile density, pile angle, and moisture content. Specific gravity is the ratio of the weight of a material to its volume. Specific gravity measurements were carried out by entering 20 grams of sample into a $250 \mathrm{ml}$ measuring cup filled with $100 \mathrm{ml}$ of distilled water. Then stirred to accelerate the loss of air between particles. The final volume measurement is carried out after the volume becomes constant. (Khalil 1999). Specific gravity is calculated by the formula:

$$
\text { Specific gravity }=\frac{\text { feed material weight }(\mathrm{kg})}{\text { Change aqua dest volume }(\mathrm{l})}
$$

Pile density is the ratio between the weight of the feed material and the volume of space it occupies. The pile density value is inversely proportional to the water content and foreign particles in the feed ingredients (Syamsu et al 2015). Samples weighing 60 grams were poured into a $250 \mathrm{ml}$ measuring cup with the 
help of a plastic funnel. Then measure the height of the sample in the measuring cup by looking at the volume of the measuring cup (Syamsu et al 2015). The stack density is calculated by the formula:

$$
\text { stack density }=\frac{\text { material weight }(\mathrm{g})}{\text { material space volume (l) }}
$$

The pile angle is the angle formed between the flat plane and the slope of the pile of material when it is poured from a certain height into a flat plane. The stack angle indicates the feed material flow rate. The pile angle was measured by dropping the sample from a certain height using a funnel until the sample fell on a flat surface with white manila cardboard. The diameter of the sample pile was measured by the flat part formed (Syamsu et al. 2015). The pile angle value is measured by the pile height $(t)$ and the bottom diameter $(\mathrm{d})$. then calculated by the formula:

\section{Sudut Tumpukan $(\operatorname{tg} \alpha)=\frac{2 \mathrm{t}}{\mathrm{d}}$}

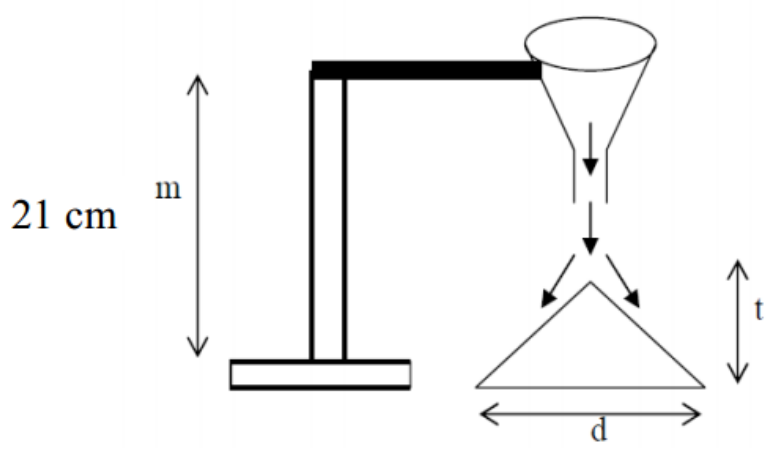

Figure 1 Pile angle measurement method

Moisture content is the water content contained in a feed ingredient that can be expressed in wet weight and dry weight. Measurement of water content was carried out by weighing a sample of 2 grams. The sample was then put into a porcelain dish and dried in a dish in an oven at $105{ }^{\circ} \mathrm{C}$ for 3 hours. After 3 hours, the sample was weighed again at its final weight. Calculation of water content using the formula (AOAC 2005):

$$
\begin{aligned}
& \text { water content }(\%) \\
& =\frac{\text { initial weight }(\mathrm{g})-\text { final weight }(\quad)}{\text { initial weight }(\mathrm{g})} \times 100
\end{aligned}
$$

\section{Data analysis}

The design used in the physical properties data obtained was a factorial $2 \times 4$ Completely Randomized Design (CRD) with 5 replications where factor a was feed ingredients (pollard and wheat bran), factor $b$ was organic acid (without organic acid, sorbic acid, propionic, and lauric acid).
The mathematical model of a $2 \times 4 \times 5$ Factorial Completely Randomized Design is as follows:

$$
X_{n p q}=\mu+\alpha p+\beta q+(\alpha \beta)_{p q}+(\alpha \beta \gamma)_{p q r}+e_{n p q r}
$$

with :

Xnpq: Observations on the nth experimental unit of the combination of treatment pq with factor A level to $\mathrm{p}$ and factor $\mathrm{B}$ to level q.

$\mu \quad$ : average age

ap : average effect of factor a on the level to $\mathrm{p}$

$\beta q \quad$ : average effect of factor $b$ on the level to $\mathrm{q}$

$(\alpha \beta)_{\mathrm{pq}}$ : the interaction effect of factor a level to $p$ and factor $b$ level to $q$

$\mathrm{e}_{\mathrm{npq}}$ : The effect of errors/errors that arise from the combination of the nth experiment in factor $\mathrm{A}$ at level $\mathrm{p}$ and factor B at level $\mathrm{q}$

The physical properties data obtained were analyzed using variance (ANOVA). If 
there is a significant difference, the data will be tested further with Duncan's test. Determination of the best treatment is done by using the effectiveness index test method (DeGarmo, et al 1984). Each parameter is assigned a variable weight (BV) with the number $0-1$. The amount of weight is determined based on the level of importance of the parameter. The higher the level of importance, the higher the value of the given variable weight. The normal weight $(\mathrm{BN})$ of each parameter is determined by dividing $\mathrm{BV}$ by the sum of all variable weights. The value of effectiveness $(\mathrm{Ne})$ is obtained by the formula:

effectiveness value ( $\mathrm{Ne})$

$=\frac{\text { treatment value }(\mathrm{NP})-\text { worst value }(\mathrm{NBr})}{\text { best value }(\mathrm{NBk})-\text { worst value }(\mathrm{NBr})}$
The result value (Nh) of each parameter is determined from the result of multiplying the effectiveness value $(\mathrm{Ne})$ with the normal weight (Bn). The result value of each parameter is added up to find out the total value of the result. The highest total yield value $(\mathrm{Nh})$ indicates the best treatment result.

\section{RESULTS AND DISCUSSION}

Pollard is the outermost part of the wheat husk which is commonly used as animal feed. Pollard is also a source of dietary fiber and also contains protein, fat, minerals, and vitamins.

Table 1 Physical and nutrient properties of materials

\begin{tabular}{lcc}
\hline \multirow{2}{*}{ Component } & \multicolumn{2}{c}{ Feed ingredients } \\
\cline { 2 - 3 } & Pollard & Wheat bran \\
\hline a nutrient content (\%) & 11,96 & 12,78 \\
Water content & 3,87 & 4,28 \\
Dust & 16,20 & 15,93 \\
Crude protein & 4,24 & 2,41 \\
Crude fat & 6,30 & 6,31 \\
Crude fiber & & \\
\hline b physical value & 1,38 & 2,67 \\
Specific gravity $(\mathrm{kg} / \mathrm{l})$ & 295 & 303 \\
Stack density (kg/m $\left.{ }^{3}\right)$ & 37,3 & 28,9 \\
Stack angle (') & & \\
\hline
\end{tabular}

Source: a Julaeha 2020, bIrawan 2006

The results of the physical quality test of pollard with the addition of several types of

organic acids can be seen in Tables 2 and 3:

Table 2. Effects of adding organic acids on pollard

\begin{tabular}{lllll}
\hline \multirow{2}{*}{ Parameter } & \multicolumn{4}{c}{ Types of organic acids (1\%) } \\
\cline { 2 - 5 } & \multicolumn{1}{c}{ Control } & \multicolumn{1}{c}{ Sorbic acid } & Propionate acid & \multicolumn{1}{c}{ Lauric acid } \\
\hline Water content $(\%)$ & $13,3 \pm 0,23^{\mathrm{a}}$ & $13,59 \pm 0,16^{\mathrm{a}}$ & $13,02 \pm 0,11^{\mathrm{a}}$ & $15,22 \pm 0,85^{\mathrm{b}}$ \\
Stack angle ( $)$ & $35,1 \pm 2,9^{\mathrm{a}}$ & $33,2 \pm 2,4^{\mathrm{a}}$ & $25,3 \pm 5,4^{\mathrm{ab}}$ & $25,7 \pm 3,1^{\mathrm{b}}$ \\
Stack density $\left(\mathrm{kg} / \mathrm{m}^{3}\right)$ & $228 \pm 5,7$ & $244 \pm 5,3$ & $246 \pm 5,2$ & $246 \pm 5,4$ \\
Stack angle $(\mathrm{kg} / \mathrm{l})$ & $1,16 \pm 0,14$ & $1,03 \pm 0,06$ & $1,04 \pm 0,12$ & $1,34 \pm 0,28$ \\
\hline
\end{tabular}

Source: Analysis results at the feed industry technology laboratory. IPB (2021).

Notes: Means in the same row with different superscripts differ significantly $(\mathrm{P}<0.05)$. 
Wheat bran or wheat bran is the deepest part of wheat which is commonly used as a mixture in the process of making animal feed.
The results of the physical quality test of wheat bran added with organic acids are as follows:

Table 3. Effects of adding organic acids on wheat bran

\begin{tabular}{lcccc}
\hline \multicolumn{1}{c}{ Parameter } & \multicolumn{4}{c}{ Types of organic acids (1\%) } \\
\cline { 2 - 5 } & Control & Sorbic acid & Propionate acid & Lauric acid \\
\hline Water content $(\%)$ & $14,72 \pm 1,19$ & $15,10 \pm 0,37$ & $13,92 \pm 0,89$ & $15,48 \pm 0,19$ \\
Stack angle () & $23,6 \pm 7,1$ & $27,4 \pm 5,2$ & $28,6 \pm 5,3$ & $22,4 \pm 5,6$ \\
Stack density $\left(\mathrm{kg} / \mathrm{m}^{3}\right)$ & $286 \pm 5,6$ & $279 \pm 5,4$ & $293 \pm 5,5$ & $291 \pm 5,6$ \\
Stack angle $(\mathrm{kg} / \mathrm{l})$ & $2,44 \pm 0,76$ & $1,76 \pm 0,40$ & $2,35 \pm 0,04$ & $2,61 \pm 0,66$ \\
\hline
\end{tabular}

Source: Analysis results at the feed industry technology laboratory. IPB (2021).

Notes: Means in the same row with different superscripts differ significantly $(\mathrm{P}<0.05)$.

\section{Water Content of Pollard and Wheat Bran}

Based on the results of the analysis of the variance of feed types (Table 2) had a significant effect on water content $(\mathrm{P}<0.05)$. These results indicate that the different types of feed in this study will affect the value of the water content produced. This difference in results was caused by the initial moisture content (Table 1) of each type of feed before storage. Based on the results of the ANOVA test, it was also known that the type of organic acid significantly affected the water content of the pollard $(\mathrm{P}<0.05)$. These results indicate that the addition of organic acids has an effect on pollard during storage.

In Table 2 it is known that the lowest water content $(13.02 \%)$ was found in the pollard treatment with the addition of $1 \%$ propionic acid and the highest water content $(15.22 \%)$ was found in the pollard treatment with the addition of $1 \%$ lauric acid. This shows that the addition of lauric acid is not effective in maintaining the quality of the water content of pollard because it has the highest water content and is even worse than pollard which does not add organic acid. While pollard with the addition of sorbic acid $(13.59 \%)$ has a lower water content when compared to pollard without organic acid, but the water content in sorbic acid treatment is higher when compared to pollard treatment with the addition of propionic acid. These results indicate that the treatment with the addition of propionic acid is the best. Based on the initial data before storage pollard has a water content of $11.96 \%$ after being stored for 6 weeks pollard water content becomes $13.3 \%$ which means an increase of $1.34 \%$. In pollard with the addition of propionic acid, the water content increased by $1.06 \%$. This result is better when compared to pollard with the addition of lauric acid which has an increase in water content of 3.2

Table 4. Temperature and humidity during storage

\begin{tabular}{ccc}
\hline Week & Temperature $\left({ }^{\circ} \mathrm{C}\right)$ & Humidity $(\%)$ \\
\hline 1 & 26 & 81 \\
2 & 23 & 72 \\
3 & 24 & 74 \\
4 & 23,5 & 74 \\
5 & 24,5 & 69 \\
6 & 22,5 & 78 \\
Average $^{\text {a }}$ & 23,9 & 74,6 \\
\hline
\end{tabular}

According to Julaeha (2020), a factor that greatly influences the decline in the quality of food products is changes in the water content in the product. Changes in feed quality 
characteristics can be seen from changes in water content before and after storage because water is one of the components of the feed material itself. Changes in water content that occurred in the pollard were caused by the temperature of the storage environment for 6 weeks ranging from $23.9^{\circ} \mathrm{C}$ and the pollard was stored in an open place with a humidity of $74.6 \%$. The temperature and humidity during the study were not ideal for storage of feed ingredients because according to Syarief and Halid (1993) that the safe limit of storage temperature for agricultural products ranged from 27-30 ${ }^{\circ} \mathrm{C}$ with a safe limit of storage humidity of less than $70 \%$. High humidity in the storage process supports the high water content stored in feed ingredients. This also shows that pollards can absorb water from the environment. This opinion is also supported by the statement of Syahri (2018) which states that the high humidity of the storage room air can cause the absorption of water vapor from the air to the ration which increases water content. However, this can be inhibited by the addition of propionic acid.

Propionic acid and its sodium and calcium salts are effective preservatives against fungi. These compounds also slightly inhibit bacterial growth. The way propionic acid works in preserving is by lowering the $\mathrm{pH}$ of food so that microbes cannot live to damage food products. Microbes are invisible creatures that have cells in their bodies. Cells themselves are made up of water molecules. The increase in low water content that occurs in the addition of propionic acid can be caused by the presence of a small number of microbes in the pollard. According to Utama et al (2019), the presence of the number of mold colonies in the feed can increase the water content of the treatment.

Based on the results of the variance test (Table 3), it was found that organic acids had no significant effect on water content $(P>0.05)$. These results indicate that there is no significant change between wheat bran that has been stored without organic acids and wheat bran with the addition of organic acids. In Table 3 it is known that the lowest water content occurs in wheat bran with the addition of propionic acid (13.92). When compared with the control $(14,72)$, the treatment with the addition of propionic acid was the best, although it was necessary to test the effectiveness index to determine which treatment was the best.

The moisture content of wheat bran in all treatments increased when compared to the water content before storage (Table 1), namely $12.78 \%$ which was stored for 6 weeks, the water content of wheat bran increased by $1.94 \%$. This result is greater when compared to wheat bran with the addition of propionic acid which is $1.14 \%$, but this result is smaller when compared to wheat bran with the addition of lauric acid which is $2.7 \%$. These results indicate that lauric acid is not suitable for use as a preservative in pollard and wheat bran because it causes a more significant increase in water content compared to pollard and wheat bran without the addition of organic acids. After all, a high increase in water content will support the growth of microorganisms that cause faster decay. occur and ultimately reduce the quality and shelf life of the product.

\section{Specific Gravity of Pollard and Wheat Bran}

Specific gravity is the ratio of the weight of a material to its volume. Based on the results of the analysis of the variance of the type of feed affecting the specific gravity $(\mathrm{P}<0.05)$ this was due to the different particle sizes of the two materials used which caused the specific gravity value of pollard to be much lower than that of wheat bran. The large particle size will reduce the specific gravity value because the feed will tend to float if the density is tested. This happens when the density of the material is less than the density of water $1(\mathrm{~kg} / \mathrm{l})$. While pollard and wheat bran have a density greater than water, this is evidenced by pollard and wheat bran sinking when added water.

In Table 1 it is known that pollard has a specific gravity of $1.38 \mathrm{~kg} / \mathrm{l}$ and wheat bran 2.67 $\mathrm{kg} / \mathrm{l}$ after storage for 6 weeks the specific gravity of pollard becomes $1.16 \mathrm{~kg} / \mathrm{l}$ and wheat bran becomes $2.44 \mathrm{~kg} / \mathrm{l}$. . These results indicate that the length of storage time will reduce the specific gravity of the material. The decrease in specific gravity was thought to be due to the increase in water content that occurred in all treatments. According to Nilasari (2012) the longer the feed is stored, the specific gravity of the feed will decrease due to an increase in water 
content and a decrease in ash content. This decrease in specific gravity is also suspected by the occurrence of a decrease in the nutrient content of the material during storage so that the mass in the material also decreases. This statement is in line with the opinion of Muklis (2017) which states that the protein and fat of the feed will decrease with the length of storage. This decrease in protein can be caused by the activity of microorganisms that require protein to continue to proliferate, while the decreased fat can be caused by oxidation activity that continues to occur during material storage.

Based on the results of the variance of organic acids, it did not affect the specific gravity $(\mathrm{P}>0.05)$ of pollard and wheat bran. These results indicate that $1 \%$ organic acid does not increase the density of the material because the amount is too small so that it does not affect the density in the material. Because specific gravity is the ratio of the density of the material to its volume when it is in water. Based on the data in Table 2, it is known that the lowest specific gravity occurred in the addition of sorbic acid $(1.03 \mathrm{~kg} / \mathrm{l})$ to the pollard. While the highest specific gravity occurred in the addition of lauric acid $(1,34)$ in the pollard. In Table 1 it is known that the addition of sorbic acid (1.76) to wheat bran resulted in the lowest specific gravity while the addition of lauric acid (2.61) to wheat bran gave the highest density. Based on these results, it was found that the addition of sorbic acid to the feed had a lower specific gravity than the addition of lauric acid to different types of feed. Wahyuni (2017) states that sorbic acid is a straight chain of unsaturated fatty acids with a molecular weight of sorbic acid of $112.13 \mathrm{~g} / \mathrm{mol}$ while the molecular weight of lauric acid is $200.31 \mathrm{~g} / \mathrm{mol}$. This shows that the low molecular weight is directly proportional to the low specific gravity. According to Wahyuni (2017), the mechanism of sorbic acid in preventing microbial growth is to prevent the dehydrogenase enzyme from working on organic acids. The structure of -diene can prevent the oxidation of fatty acids by these enzymes. This means that the inhibition of fat oxidation in feed ingredients can cause a decrease in specific gravity. Lauric acid is generally found in coconut oil (VCO) lauric acid is also a saturated fatty acid that does not have double bonds, meaning that the rancidity process will be greater when compared to double bond fatty acids, but this needs to be reviewed further in further research. Specific gravity is a determining factor for the homogeneity and stability of the mixing of feed particles.

The treatment with the addition of lauric acid $(1.34 \mathrm{~kg} / \mathrm{l})$ on pollard was the treatment with the highest specific gravity even when compared to the treatment without the addition of organic acid $(1.16 \mathrm{~kg} / \mathrm{l})$ this indicates that lauric acid has the highest fat content if compared to sorbic acid and propionic acid. This is following the opinion of Hadiwiyoto (1994) which states that storage in milk causes an increase in specific gravity due to fat compaction. The density of milk varies according to the length of time the milk is left at room temperature, where the specific gravity close to the time of milking is smaller than the density that is far from the time of milking, partly due to the compaction of fat.

\section{Pillard Density of Pollard and Wheat Bran}

Pile density is the ratio between the weight of the material and the volume of space occupied. with units of $\mathrm{kg} / \mathrm{m} 3$ (Khalil. 1999). Based on the results of the test of variance of the type of feed had a significant effect $(\mathrm{P}<0.05)$ on the density of the pile this was due to the different particle sizes of these two materials. According to Jaelani (2016), particle size affects pile density, namely a real reduction in particle size will cause an increase in the pile density value in feed ingredients. Based on Table 1, it is known that the heap density value of pollard is $295 \mathrm{~kg} / \mathrm{m} 3$ while wheat bran is $303 \mathrm{~kg} / \mathrm{m} 3$ after storage there is a decrease in the value of pollard heap density to $228 \mathrm{~kg} / \mathrm{m} 3$ (Table 2) and wheat bran $286 \mathrm{~kg} / \mathrm{m} 3$ (Table 3). . These results indicate that the length of storage time causes a decrease in the value of stack density, this is presumably by a decrease in the nutrient content in the material which causes the intermolecular space in the feed to become large so that the volume of the space also enlarges. Based on Tables 2 and 3, organic acids did not affect $(\mathrm{P}>0.05)$ the density of pollard and wheat bran piles. These results indicate that the addition of organic acids does not increase the volume of the material. Specific density plays an important 
role in calculating the volume of space required for storage and filing of the mixer. According to Julaeha (2020), mixing feed ingredients using the same particle size but having a large pile density (more than $500 \mathrm{~kg} / \mathrm{m} 3$ ) will make it difficult for the ingredients to be mixed and allow the ingredients to separate from the mixture. Feeds having a low pile density of less than $450 \mathrm{~kg} / \mathrm{m} 3$ requires a longer saturation time or mixing

\section{Pillar Angle of Pollard and Wheat Bran}

Pile angle It is the angle formed between the flat plane and the slope of the pile when the material is poured from a certain height onto the flat plane. Based on the results of the analysis of variance, it was found that the type of feed had a significant effect $(\mathrm{P}>0.05)$ on the stack angle. As for the type of organic acid, it significantly affected the pollard stack angle $(\mathrm{P}<0.05)$ but had no significant effect $(\mathrm{P}>0.05)$ on the wheat bran stack angle.

Based on Table 2, it is known that the smallest pile angle occurs in pollard added with propionic acid (25.3') while the largest pile angle is experienced by pollard without organic acid added (35.1'). In Table 3 the largest stack angle (28.6') occurs in wheat bran added with propionic acid while the smallest stack angle (22.4') occurs in wheat bran added lauric acid. Su'i (2015) said that the longer the storage time, the higher the particle size, the higher the stack angle, which will damage the quality of the feed ingredients. This means that the desired stack angle is the smallest. There is a fundamental difference that occurs in this study, namely the addition of propionic acid to pollard and wheat bran. This is due to the different particle sizes of the feed ingredients and the mechanism of action of propionic acid may be influenced by the structure of the feed material. However, this needs further rest.

The addition of propionic acid to pollard is considered to be able to maintain the quality of the pollard considering that when compared with other treatments the addition of propionic acid to pollard gives the lowest value, which means that the physical quality of the pollard is still maintained after 6 weeks of storage. However, the addition of propionic acid to wheat bran gives the opposite result. The increase in the stack angle also shows the characteristics of the material particles when moving narrowly, the harder a particle moves, the larger the stack angle it forms. The material flow rate indicator affects the process of moving and transporting feed ingredients.

\section{Best Treatment Effectiveness Test Addition of Organic Acid}

Based on the test results the addition of several types of organic acids in pollard and wheat bran. So the best treatment is taken from the parameters of water content $(\mathrm{Ka})$, specific gravity $(\mathrm{Bj})$, pile density $(\mathrm{KT})$, and pile angle (ST). Determination of the best treatment was taken using the effective index method (DeGarmo. et al, 1984) which can be seen in appendix 9. The calculation using the effective index method gave the results of the average value of the relationship between the weight value and the largest treatment value which was the best treatment. Each parameter is given a variable weight with a number $0-1$ based on the level of importance of the parameter in determining quality. The more important it is, the greater the value of the given variable weight. The result value of each parameter is added up to find out the total value of the result. The highest total value is the best treatment.

Table 5. The total value of the results of each treatment

\begin{tabular}{ccccc}
\hline Parameter & \multicolumn{4}{c}{ Organic acid treatment yields value $^{\mathrm{s}}$} \\
\cline { 2 - 5 } & Control & Sorbic acid & Propionic acid & Lauric acid \\
\hline Pollard & 0 & 0,35 & 0,77 & 0,64 \\
Wheat bran & 0 & $-1,39$ & 2,64 & 1,07 \\
\hline
\end{tabular}

Based on Table 5, it can be concluded that in pollard it is known that the highest total yield value occurs in the treatment of adding propionic acid. This shows that the provision of 
propionic acid to pollard that has been stored for 6 weeks still shows good physical quality. While in wheat bran, it is known that the total value of the highest effectiveness test results occurs in the treatment of adding propionic acid to wheat bran that has been stored for 6 weeks. This shows that propionic acid treatment is the best treatment in this study. store pollard and wheat bran with the Arrhenius model acceleration method will add propionic acid as a preservative for pollard and wheat bran. To estimate the expiration date of the addition of propionic acid as a preservative.

\section{CONCLUSION}

In this research, it can be concluded that organic acids have an effect on pollard moisture content and pollard pile angle but have no effect on pile density, the density of pollard, and wheat bran.

\section{DAFTAR PUSTAKA}

AOAC. 2012. Official Methods of Analysis. Arlington (US): The Association Of Official Analytical Of Chemist.

DE GARMO, E.P., W.G. SULLIVAN., DAN C.R. CANDRA. 1984. Engineering Economi.7th edition. Mc Millan Publ. Co. New York.

IRAWAN. H. 2006. Karakteristik sifat fisik jagung, dedak padi dan pollard. [Skripsi]. Ilmu nutrisi dan makanan ternak. Fakultas peternakan. Institut pertanian bogor. Bogor.

JAELANI A, DHARMAWATI S, DAN WACAHYONO. 2016. Pengaruh Tumpukan Dan Lama Masa Simpan Pakan Pellet Terhadap Kualitas Fisik. Ziraa'ah, vol 41 no 2 hal 261-268

JULAEHA S. 2020. Evaluasi wafer konsentrat dengan taraf wheat bran dan lama pemanasan yang berbeda. [Skripsi]. Ilmu nutrisi dan teknologi pangan. Fakultas peternakan. Institut pertanian bogor. Bogor.

KHALIL. 1999. Pengaruh Kandungan Air Dan Ukuran Partikel Terhadap Sifat Fisik Pakan Lokal, Kerapatan Tumpukan Pemadatan Tumpukan, Dan Berat Jenis. Media Peternakan. 22(1):1-11.
NILASARI. 2012. Pengaruh penggunaan tepung ubi jalar garut dan onggok terhadap sifat fisik dan lama penyimpanan ayam broiler bentuk pellet. [Skripsi]. Institut Pertanian Bogor. Bogor.

NOSAL E. REINPRECHT L. 2019. Antibacterial and anti-mold efficiency of silver nanoparticles present in melamine laminated particleboard surfaces. Bioresources.vol 1: 1-13

PATTY PV. 2015. Pengaruh lama fermentasi terhadap ranciditas minyak kelapa yang diproduksi secara tradisional. Biopendix 1: 137-142. DOI: 10.30598/biopendixvol1issue2page146152.

SYAHRI M. RETNANI Y. KHOTIJAH L. 2018. Evaluasi penambahan binder berbeda terhadap kualitas fisik mineral wafer. Bulletin makanan ternak. Vol 1: 1-7

SU'I. M. SUMARYATI E. PRASETYO R. 2015. Anti-bacteria activities of lauric acid from coconut endosperm (Hydolysed using lipase endogenous). Advances in environmental biology. Vol 9: 45-49

SUKASIH E. SETYADJIT. 2016. Formulasi antifungal kombinasi dari ekstrak limbah mangga dengan pengawet makanan komesial untuk preservasi buah manga. Jurnal penelitian pascapanen pertanian. Vol 14: 22-34.

SYAMSU JA, YUSUF M, ABDULLAH A. 2015. Evaluation Of Physical Properties Of Feedstuffs In Supporting The Development Of Feed Mill At Farmers Group Scale. Journal Advan Agri. Tech.2 (2): 147-150

UTAMA CS, ZUPIZAL, HANIM C, WIHANDOYO. 2019. Pengaruh lama pemanasan terhadap kualitas kimia wheat pollard yang berpotensi sebagai prebiotik. Jurnal Aplikasi Teknologi Pangan 8: 113-122. DOI: 10.17728/jatp.5262

WAHYUNI, L.P.E., WIDJAJA, I.N.K., DAN ASTUTI, N.M.W., 2017. Analisis 
Kualitatif Asam Oleat Pada Minyak Kelapa Sub Varietas Genjah. Skripsi. Bali. Jurusan Farmasi Fakultas Matematika Dan Ilmu Pengatahuan Alam. Universitas Udayana. 